\title{
CONSUMER OVER-INDEBTEDNESS LANDSCAPE: THE OBLITERATION OF A CREDITOR-ORIENTED APPROACH THROUGH THE DEBT INTERVENTION PROCEDURE?
}

\author{
by Khalipha Shange*
}

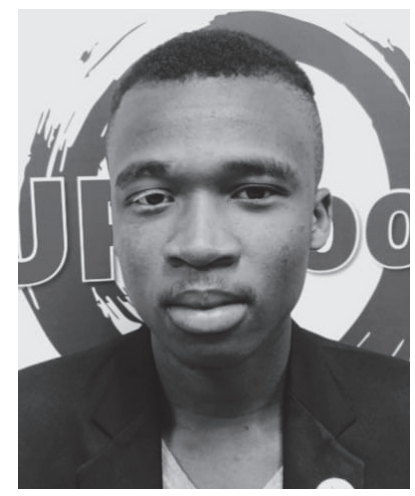

'You are either alive and proud, or you are dead and when you are dead, you can't care anymore' - Steve Bantu Biko

\section{Introduction}

As observed by Coetzee and Roestoff, the South African natural person insolvency system remains creditor oriented and as a ramification many over-indebted consumers are excluded from access to debt alleviation measures. ${ }^{1}$ There are three debt alleviation measures available to natural persons in South Africa, of which only the sequestration procedure under the Insolvency Act provides an over-indebted consumer with a discharge from pre-insolvency debts. ${ }^{2}$

* Final year LLB Student (University of Pretoria), Justice of the Student Court (University of Pretoria), 2020. ORCID: 0000-0003-0429-6999. I would like to express my greatest gratitude to Prof $\mathrm{H}$ Coetzee for her insight reviews, patience and encouragement.

$1 \quad H$ Coetzee \& $M$ Roestoff 'Rectifying an unconstitutional dispensation? A consideration of proposed reforms relating to No Income No Asset debtors in the South African insolvency system' (2020) International Insolvency Review 1.

2 Insolvency Act 24 of $1936 \mathrm{sec} 9(1)$; R Leathern 'Consideration of the proposed debt intervention procedure from a debt relief perspective' (LLM thesis University of Pretoria 2018) IV (thereafter 'Leathern'). 
However, the principal requirement of proving financial advantage to creditors restricts access for many debtors as they do not have sufficient disposable assets to satisfy the requirement. ${ }^{3}$ The other two debt alleviation measures are the administration order provided in the Magistrates Court ${ }^{4}$ and debt review under section 86 of the National Credit Act. ${ }^{5}$ These measures have been heavily criticised for their reliance on the courts and for only providing debt repayment plans with no provision for discharge. ${ }^{6}$

This article commences with a detailed discussion of the debt intervention procedure provided by the 2019 National Credit Amendment Act. ${ }^{7}$ Thereafter, the New Zealand insolvency system is discussed. The purpose is to benchmark the debt intervention procedure against the New Zealand insolvency system in order to ascertain if it obliterates a creditor-oriented approach.

\section{The debt intervention procedure}

The introduction of the 2019 Amendment Act is inherently embedded in the endeavour to rectify unfair discrimination experienced by overindebted consumers who have no recourse for debt alleviation. ${ }^{8}$ In this regard the 2019 Amendment Act undertakes to alter the legal position regarding debt alleviation mechanisms by providing certain over-indebted consumers with access to the new debt intervention procedure inserted into the National Credit Act as section 86A. During this process the National Credit Regulator (NCR) is empowered to do various evaluations; of the most important being a referral of the matter to the Tribunal (NCT) or court if the consumer is found to be over-indebted. ${ }^{9}$

\subsection{Application and access requirements}

The scope of application of the debt intervention procedure is restricted by the access requirements stipulated in the definition of a debt intervention applicant and section 86A of the 2019 Amendment Act. ${ }^{10}$ Section $86 \mathrm{~A}$ stipulates that '[a] natural person debt intervention applicant may apply to the National Credit Regulator in order to be declared over-indebted' provided that the total

Leathern (n 2 above) IV.

4 Magistrates Court Act 32 of 1944.

5 National Credit Act 34 of 2005 (thereafter 'NCA'); See also Leathern (n 2 above) IV.

6 Leathern (n 2 above) IV.

7 National Credit Amendment Act 7 of 2019 (thereafter the '2019 Amendment Act').

8 Coetzee \& Roestoff (n 1 above) 2.

92019 National Credit Amendment Act (n 7 above) sec 86A(1).

102019 National Credit Amendment Act (n 7 above) sec 86A. 
unsecured debt of the 'debt intervention applicant' does not exceed the R50 000 threshold. ${ }^{11}$

Furthermore, with regards to the procedure's application, the definition of a debt intervention applicant refers to unsecured debt only thus implying that over-indebted consumers who are party to a secured credit agreement are not eligible to apply for the procedure. ${ }^{12}$ Any consumer party to a 'developmental credit agreement $^{\prime 13}$ or a credit agreement in which the creditor has since taken steps to enforce the agreement, is disqualified from admission to the debt intervention procedure, as contemplated by section $86 \mathrm{~A}(2) .{ }^{14}$ It is important to note that a secured credit agreement is not mentioned in section $86 \mathrm{~A}(2)$ as being disqualified. Therefore, as stated by Coetzee and Roestoff, creating the impression that not only are secured credit agreements excluded from the application of the procedure but are further disqualified in total, as it appears that only an applicant with unsecured credit agreements regulated by NCA can access the procedure. ${ }^{15}$

The other notable access requirement is that the applicant must not receive gross income exceeding the prescribed threshold of R7 500 per month on an average for the six months preceding the date of application for admission into the debt intervention procedure or an amount prescribed in terms of section $171(2 \mathrm{~A})$, per month. ${ }^{16}$ Section 171(2A) empowers the Minister of Finance to annually adjust both the threshold of gross income of R7 500 per month and R50 000 unsecured total debt with due consideration to inflation. ${ }^{17}$ Moreover, the procedure applies to the explicit exclusion of consumers who have been sequestrated or have been subjected to an administration order. ${ }^{18}$

112019 National Credit Amendment Act (n 7 above) sec 86A(1).

122019 National Credit Amendment Act (n 7 above) sec 1(b).

13 According to sec 10(1) of NCA a credit agreement will be a developmental credit agreement irrespective of its form, type, category if at the time the agreement is entered into the credit provider holds supplementary registration certificate issued in terms of sec 41 and the loan must be for educational purposes, acquisition or expansion of low-income housing or development of small businesses.

14 Coetzee \& Roestoff (n 1 above) 13.

15 As above.

162019 National Credit Amendment Act (n 7 above) sec 1(b)(b).

172019 National Credit Amendment Act (n 7 above) sec 171(2A).

182019 National Credit Amendment Act (n 7 above) sec 1(b)(b). 


\subsection{Assessment of application by NCR}

Upon receiving the debt intervention application, $\mathrm{NCR}^{19}$ must adhere to section 86(4) and (6) of the National Credit Act (which deals with the debt review procedure under section 86 ) in order to initiate the assessment process, mainly by furnishing the debt intervention applicant with proof of application and informing all listed creditors and all registered credit bureaus of the application, so they can all cooperate with the NCR's requests in good faith. ${ }^{20}$

However, when considering the application, there are certain duties imposed on NCR, such as providing an applicant to the procedure with financial literacy counseling and access to training intended to improve the applicant's financial literacy. ${ }^{21}$ After having completed the assessment, NCR must accept or reject the application based on whether the applicant qualifies for the procedure or not. Then NCR must further examine whether the applicant is overindebted or whether any of the applicant's credit agreements appear to be reckless, ${ }^{22}$ unlawful, ${ }^{23}$ or prohibited, ${ }^{24}$ and, if so, refer such a matter to the National Consumer Tribunal (NCT). ${ }^{25}$

It may happen that an applicant does not qualify for the procedure, but is likely to, or experiences difficulty with the satisfaction of credit agreement obligations. ${ }^{26}$ In such instances, NCR is empowered to propose that the applicant together with the affected credit providers voluntarily enter into a debt re-arrangement plan. ${ }^{27}$ It is important to note that if NCR rejects the application for debt intervention, an applicant may approach the Magistrate's Court directly for an order stipulated in section $87 .{ }^{28}$ From an analysis perspective section 87 in its entirety is the most significant part of the debt intervention process as it contains orders which can be made in respect of the procedure which includes, amongst others, the suspension, rearrangement and extinguishment of the whole or a portion of the total unsecured debt.

The NCR's referral to NCT must be accompanied by a recommendation for an appropriate order, for applicants who have qualified for the procedure. The NCR, consistent with section 87(1A),

19 The office of NCR is responsible for economic and social advancement in the credit industry, its tasks include among others investigation of complaints, facilitating research and educational projects, and more importantly ensuring compliance with NCA.

20 Coetzee \& Roestoff (n 1 above) 14.

212019 National Credit Amendment Act (n 7 above) sec 86A(5).

22 National Credit Act (n 5 above) secs 80-83.

23 National Credit Act (n 5 above) sec 89

24 National Credit Act (n 5 above) secs 74, 75, 81(3) for example.

25 Coetzee \& Roestoff (n 1 above) 15.

262019 National Credit Amendment Act (n 7 above) sec 86A(6)(b).

27 As above.

282019 National Credit Amendment Act (n 7 above) sec 86A(7). 
may recommend that NCT rearranges debt obligations of a qualifying applicant for a period of not more than 5 years. ${ }^{29}$ This re-arrangement depends on whether the applicant has enough income and assets to satisfy the obligations in terms of the re-arrangement. ${ }^{30}$

However, for applicants who qualify for the procedure, but who do not have sufficient income and assets to satisfy re-arrangement obligations, NCR must recommend the matter to NCT for a section 87A(3) order of debt extinguishment. ${ }^{31}$ Furthermore, NCR must inform all affected creditors of such a referral and extend the invitation to make formal written presentations to NCT at a certain date. ${ }^{32}$ Section $87 \mathrm{~A}(3)$ has been heavily criticised by creditors as amounting to unconstitutional deprivation of property ${ }^{33}$ as prohibited by section 25 of the Constitution of the Republic of South Africa ${ }^{34}$ and this criticism may serve as an alert of possible future litigation between creditors and the NCT.

In an instance where the consumer has defaulted on his payments and is in arrears with three or more payments such agreement will be classified as being impaired. ${ }^{35}$ Therefore where an impaired credit agreement is subject to a debt intervention application procedure, a creditor may terminate the procedure by informing both the applicant and NCR of such termination, but this termination may only be done after a prescribed period (because the Act only refers to a 'prescribed period' but does not explicitly state the period it can be assumed that such a period must be stipulated by the creditor in the notice of termination). ${ }^{36}$ It is however not possible for the creditor to terminate the procedure where the matter has been escalated and filed with the NCT. ${ }^{37}$ Moreover, regardless of the fact that the procedure was terminated properly, a court or NCT hearing the matter, may order the resumption of the procedure on grounds that it deems just. ${ }^{38}$

\subsection{Referral to NCT and consequences of debt intervention}

When reflecting on the debt intervention procedure Coetzee and Roestoff observe that it is notable that NCT has the most important functions that are aligned with the best international practices and guidelines of insolvency law. ${ }^{39}$ After a referral was made, NCT has an 
obligation to consider information presented by the affected parties as well as any other relevant information to ascertain whether the applicant qualifies for the procedure or not. ${ }^{40}$ Subsequently, NCT may reject or approve the application based on further factors provided by section 87 such as whether the applicant is a 'minor heading a household, a woman heading a household or an elderly person'. 41

Upon approval of the application, section $87 \mathrm{~A}(2)(\mathrm{b})$ states that NCT may suspend all the credit agreements, partially or in full for a period of 12 months, which after expiry may be extended further by another period of 12 months, and require the applicant to attend further financial literacy training. ${ }^{42}$ This order may only be made after consideration of whether the applicant is disabled, a minor heading a household, a woman heading a household, or an elderly person. ${ }^{43}$ Further factors to be considered are whether the applicant has ever applied for any of the existing statutory debt relief measures or had their debt discharged by the court or NCT which, if confirmed, may strongly hinder the chances of admission to procedure. ${ }^{44}$

Apart from the abovementioned factors, the applicant's conduct is also taken into consideration with regards to commissions or omissions that have hindered the applicant's ability to qualify for the debt re-arrangement plan stipulated in section $86 \mathrm{~A}(6)(\mathrm{d})$ and the necessary steps taken to increase or attain an income. ${ }^{45}$ Other factors relate to the behaviour of affected creditors for the period when the credit agreements were concluded and during the course of proceedings in section $86 \mathrm{~A}$ and before the NCT. ${ }^{46}$ The behaviour of affected creditors must not amount to the harassment of the overindebted consumer in the process of debt collection or reckless, unlawful or prohibited lending conduct. ${ }^{47}$

With regards to the suspension of debt for applicants who do not have sufficient income and assets as contained in section $87 \mathrm{~A}(2)(\mathrm{b})$, NCR must, after 8 months into the 12 month suspension order, review the financial circumstances of the applicant in order to ascertain whether the applicant has acquired sufficient assets and income to qualify for the 5 year re-arrangement plan stipulated in section $86 \mathrm{~A}(6)(\mathrm{d}) .{ }^{48}$ If NCR ascertains that the applicant has acquired sufficient assets and income to qualify for the section $86 \mathrm{~A}(6)(\mathrm{d})$ re-

39 As above.

402019 National Credit Amendment Act (n 7 above) sec 87A(2)(a).

412019 National Credit Amendment Act (n 7 above) sec 87A(3)(a).

422019 National Credit Amendment Act (n 7 above) sec 87A(2)(b).

432019 National Credit Amendment Act (n 7 above) sec 87A(3)(a).

44 As above.

45 Coetzee \& Roestoff (n 1 above) 17.

46 Coetzee \& Roestoff (n 1 above) 18.

472019 National Credit Amendment Act (n 7 above) sec 86A(6)(c).

48 Coetzee \& Roestoff (n 1 above) 18. 
arrangement plan, it must make a referral to NCT with a recommendation for a section $87(1 \mathrm{~A})$ order. ${ }^{49}$

However, if NCR concludes that the applicant still does not qualify for the 5-year re-arrangement plan, because of insufficient assets and income, the matter must also be referred to NCT with a recommendation for a 12 month extension of the suspension. ${ }^{50}$ After the 12 month suspension has been granted, NCR must for the second time, 8 months into the 12 month extension period, assess the applicant's financial situation. ${ }^{51}$ If at such a stage the applicant has acquired sufficient assets and income and now qualifies for the section $86 \mathrm{~A}(6)$ (b) order, NCR makes a referral to NCT with a recommendation for a section $87(1 \mathrm{~A})$ order. ${ }^{52}$

The most important objective of the procedure is found in section $87 \mathrm{~A}(5)(\mathrm{c})(\mathrm{ii})$, which provides for a possibility of a discharge ordered by NCT provided that all other alleviation avenues contained in the procedure have been exhausted. ${ }^{53}$ This section provides that after NCR has conducted its second review and it concludes that the applicant still does not qualify for the 5 year re-arrangement plan due to insufficient assets and income, NCR must refer the matter to NCT to consider 'extinguishing the whole or a portion of the amounts stated in section 101(1) under a qualifying credit agreement'. ${ }^{4}$

However, NCR must also extend an invitation to creditors to make written recommendations to NCT in light of the referral for extinguishing the applicant's debt. ${ }^{55}$ There are certain factors to be considered by NCT before granting the order for extinguishing the applicant's debt, including among others the applicant's assets and income and the same factors to be considered when granting a suspension order as mentioned above. ${ }^{56}$ When granting the order for extinguishing the debt NCT also has the obligation to limit the applicant's right to apply for credit as stipulated in section 60 , to a minimum period of 6 months and maximum of 12 months. ${ }^{57}$

\section{New Zealand insolvency law}

The New Zealand Insolvency Act ${ }^{58}$ has been commended for its uncomplicated and accessible entry requirements for debt relief. ${ }^{59}$ As

Coetzee \& Roestoff (n 1 above) 19.

2019 National Credit Amendment Act (n 7 above) sec 7.

Coetzee \& Roestoff (n 1 above) 20.

Coetzee \& Roestoff (n 1 above) 21.

As above.

58 Insolvency Act 2006. 
observed by Coetzee this Act reformed the insolvency landscape by specifically providing debt alleviation to all honest but unfortunate over-indebted consumers. ${ }^{60}$ The most notable and attractive debt alleviation measure to be discussed is the 'no asset procedure' which, unlike the South African debt alleviation mechanisms, does not unfairly discriminate on the basis of an indebted consumer's financial status.

Notwithstanding that this procedure is used as a benchmark for the purposes of this article, it must be noted that a brief evaluation of the effectiveness of the procedure raised some shortcomings in its jurisdiction. These include criticisms by creditors that this procedure legitimises an easy escape from consequences arising from an indebted consumers previous irresponsible habits. ${ }^{61}$ Moreover, this procedure does not contain any provision to encourage indebted consumers to learn from their mistakes. ${ }^{62}$

Keeper states that a significant number of creditors and budget advisors lament the procedure's defect to facilitate change in indebted consumers spending and budgetary habits. ${ }^{63}$ Keeper proposes that to remedy this defect financial literacy and budgetary courses must be a precondition for a discharge of debts provided by this procedure. ${ }^{64}$ Furthermore this evaluation clearly points out that the procedure does not concern itself with preventing overindebtedness - instead its primary focus is to rather cure overindebtedness once it has come into effect. ${ }^{65}$

\subsection{No asset procedure}

This procedure is the first debt alleviation mechanism to make provision for the inclusion of an indebted consumer 'who has no realisable assets and does not have means of repaying any amount towards his or her debts'. ${ }^{66}$ The rationale behind the introduction of such a procedure was to accommodate indebted consumers who are often excluded from the application of other debt relief mechanisms because they do not have sufficient assets or income to repay their debts. 67

59 H Coetzee 'A comparative reappraisal of debt relief measures for natural person debtors in South Africa' LLD thesis, University of Pretoria (2015) 22.

60 Coetzee (n 60 above) 22

61 Keeper T ‘New Zealand's No Asset Procedure: A fresh start at No cost?’ (2014) Queensland University of Technology Law Review 14(3) 1.

62 Keeper (n 62 above) 16.

63 As above.

64 As above.

65 As above.

66 Public Act 200655 New Zealand sec 363.

$67 \mathrm{H}$ Coetzee \& $M$ Roestoff 'Consumer debt relief in South Africa-should the insolvency system provide for NINA debtors? Lessons from New Zealand' (2013) International Insolvency Review 22-27. 
The admission criteria to this procedure is very stringent considering the fact that the 'no asset'-procedure remains active for a twelve-month period, therefore it is susceptible to abuse. ${ }^{68}$ An indebted consumer can access the procedure by submitting a completed application form accompanied by a statement of affairs to an assignee. ${ }^{69}$ The assignee has been conferred certain conflicting powers such as being an adjudicator, representing the interests of the creditor, being a debt counsellor and being a finder of valid facts, all depending on the circumstances. ${ }^{70}$ The assignee may admit or reject an applicant to this procedure after consideration on whether the admission criteria were satisfied on reasonable grounds. ${ }^{71}$

The admission criteria has been divided into criteria relating to the indebted consumer's conduct and criteria relating to his financial position, from an objective perspective. ${ }^{72}$ Certain conduct such as the concealment of assets with the intention to defraud creditors may disqualify an indebted consumer from the procedure. ${ }^{73}$ An indebted consumer who has previously been admitted to this procedure or been formally declared bankrupt by a court is further disqualified from entry. ${ }^{74}$ Financially the total debt must be between the threshold of NZ\$1 000 and NZ\$40 000 with the indebted consumer having 'no realisable assets and any means of repaying the debts'.75

Brown points out that there are no guidelines provided for the determination of an indebted consumer's ability to repay the debts, instead only a budget form requiring disclosure of all household and family expenditure is provided. ${ }^{76}$ This creates the impression that the important question is whether the indebted consumer has any disposable net income. ${ }^{77}$ To clarify this impression: it appears as if indebted consumers who are employed are ineligible for this procedure as they are in a position to make continuous contributions to service their debts. ${ }^{78}$

After application for admission the assignee must send particulars of the indebted consumers assets and liabilities to known creditors. ${ }^{79}$ The indebted consumer is strictly prohibited from obtaining credit in excess of the threshold of NZ\$1 000 without prior disclosure to the

68 Coetzee \& Roestoff (n 68 above) 28.

69 Public Act (n 67 above) secs 362(1) and 362(2).

70 Coetzee \& Roestoff (n 68 above) 24.

71 Public Act (n 67 above) sec 363(1).

72 Coetzee \& Roestoff (n 68 above) 28.

73 Public Act (n 67 above) sec 364(a)-(d)

74 Public Act (n 67 above) secs 363(1)(b), (c) and 364(b).

75 Public Act (n 67 above) secs 363(1)(d) and 363(3).

76 Brown D "The financial health benefits of a quick "NAP" - New Zealand Solutions to consumer insolvency?', paper presented at the INSOL conference academic programme, Vancouver (20 June 2009) 10.

77 Brown (n 77 above) 10.

78 As above.

79 Public Act (n 67 above) sec 365. 
credit provider that he or she has applied for admission into such a procedure. ${ }^{80}$ For admission to be effected, the assignee must have sent a written notice of admission to the indebted consumer. ${ }^{81} \mathrm{~A}$ notice of admission must be sent to the creditors and advertised by the assignee who must further 'maintain a public register of persons who have been admitted to and discharged from the procedure'. 82

Admission to the procedure results in a moratorium against debt enforcement hence creditors are not permitted to commence or continue any debt enforcement proceedings after an indebted consumer has been admitted to the procedure. ${ }^{83}$ Debts that would normally be provable under bankruptcy and those which the indebted consumer owed on the date of application may not be enforced. ${ }^{84}$ It must be noted that this procedure applies to the exclusion of student loans, ${ }^{85}$ maintenance orders ${ }^{86}$ and debts relating to the Child Support Act (these debts fall under different Acts and cannot be classified into one category as secured or unsecured, except that they are all 'personal debts'). ${ }^{87}$ The indebted consumer has an obligation to notify the assignee of any change of financial circumstances that would enable repayment of any amount of the debts owed. ${ }^{88}$

Termination of the procedure can take various forms such as discretionary termination by the assignee and through the attainment of a discharge by the indebted consumer whereby the procedure has successfully run its course. The other form of termination permits a 'credit provider entitled' 89 to terminate to bring about an application for termination, this permission extends further to the indebted consumer to bring application to terminate their own procedure. ${ }^{90}$ Most important is the fact that any termination, except by discharge, lifts the prohibition imposed on debt enforcement therefore penalties and interest which may have accrued in the duration of the procedure will have to be paid by the indebted consumer. ${ }^{91}$

The assignee may further terminate the procedure if there was wrongful admission by bad faith constituted by the concealment of assets and misleading information. ${ }^{92}$ The assignee may also terminate

80 Public Act (n 67 above) sec 366.

81 Public Act (n 67 above) sec 367(1).

82 Public Act (n 67 above) sec 368 \& 448(3)-(4).

83 Coetzee \& Roestoff (n 68 above) 30.

84 Public Act (n 67 above) sec 243.

85 Public Act (n 67 above) sec 369.

86 Family Proceedings Act 1980.

87 Child Support Act 1991.

88 Public Act (n 67 above) sec 370.

89 Coetzee and Roestoff are of the opinion that a credit provider shall be entitled to terminate in an instance whereby a creditor's debt remains enforceable under a student loan.

90 Public Act (n 67 above) sec 372.

91 Public Act (n 67 above) sec 375.

92 Public Act (n 67 above) sec 373(1)(a). 
the procedure if it is satisfied that the financial circumstances of the indebted consumer have changed and repayment of debts is possible. ${ }^{93}$ Termination initiated by the assignee becomes effective when the assignee sends a notice to the indebted consumer, regardless of whether or not the indebted consumer received it. ${ }^{94}$ After sending the notice, the assignee must further notify known creditors of such termination. ${ }^{95}$ The assignee may apply for a "court preservation order' 96 after termination in an instance where the indebted consumer gained admission by concealment of assets or misleading information. 97

The procedure permits a creditor to apply for termination to the assignee provided that there are reasonable grounds for the assignee to conclude that the indebted consumer was disqualified according to the grounds of disqualification or the indebted consumer did not meet the admission requirements. ${ }^{98}$ The creditor is also permitted to apply for termination on the basis that adjudication in the form of bankruptcy would be more beneficial. ${ }^{99}$

The indebted consumer is automatically discharged from the procedure after a period of twelve-months had there been no termination thereof. ${ }^{100}$ However the discharge will be delayed if the assignee is of the opinion that, the procedure should be extended to thoroughly consider termination of the procedure and the assignee must have sent a notice of such a deferral to both the indebted consumer and known creditors. ${ }^{101}$ The notice of deferral 'must clearly state the alternative date of automatic discharge, which must not be more than 25 working days after expiry of the twelve-month period'. ${ }^{102}$

Immediately after discharge, the indebted consumer is not liable to pay any amount or portion thereto of debts that became unenforceable and cancelled. ${ }^{103}$ This discharge includes interest and penalties. ${ }^{104}$ However, debts and liabilities incurred by conduct of bad faith such as fraud or fraudulent breach of trust become enforceable on discharge including interest and penalties. ${ }^{105}$ The

93 Public Act (n 67 above) sec 372 read together with sec 373(1)(a).

94 Public Act (n 67 above) sec 373(2).

95 Public Act (n 67 above) sec 373.

96 A 'court preservation order' temporarily protects property or assets for the benefit of the creditors since the assignee gained admission by bad faith of misleading information or concealment of assets.

97 Coetzee \& Roestoff (n 68 above) 32.

98 Public Act (n 67 above) 376.

99 Coetzee Roestoff (n 68 above) 32.

100 As above.

101 Coetzee \& Roestoff (n 68 above) 33.

102 Coetzee \& Roestoff (n 68 above) 33.

103 Coetzee \& Roestoff (n 68 above) 33.

104 Coetzee \& Roestoff (n 68 above) 33.

105 Coetzee \& Roestoff (n 68 above) 33. 
discharge is only limited to the indebted consumer and not business affiliates, co-trustees, guarantors or any other person jointly and severally liable with the indebted consumer. ${ }^{106}$

\section{Concluding remarks}

It is apparent that the introduction of the debt intervention procedure in the South African insolvency system was to accommodate overindebted consumers with no realisable assets for disposal and who, as a consequence, are often excluded from any form of debt alleviation. The legislature should be commended for taking valuable lessons from New Zealand's 'no asset procedure' and providing an inexpensive and accessible mechanism for debt alleviation. ${ }^{107}$

However, it is important to mention that the introduction of the debt intervention procedure will bring about new challenges to the credit landscape just as the no asset procedure did. Contrary to the no asset procedure, the debt intervention procedure went further to make provision for financial literacy counselling and training to the applicants. This is clearly consistent with the prevention of overindebtedness by changing the attitudes of indebted consumers to the use of credit. The active participation of NCR and NCT can be compared to that of the assignee, this facilitates low-cost debt alleviation for applicants languishing in over-indebtedness especially because court alleviation measures can be costly. ${ }^{108}$

The debt intervention procedure deviates from the no asset procedure as indebted consumers who are employed can access the alleviation measure provided that their monthly income does not exceed the prescribed threshold of R7 500. ${ }^{109}$ Contrary to this Brown asserts that indebted consumers who are employed are ineligible for admission to the no asset procedure. ${ }^{110}$ This poses the question whether indebted South African consumers deserve the option of a discharge considering their employment status. From a creditor's perspective the South African legislature drew a very controversial inference from the no asset procedure - that being the discharge of a portion or the entire debt as contemplated by section 87 . Creditors have vehemently opposed the provision for discharge of debts, citing concerns that such would amount to unconstitutional deprivation of property. ${ }^{111}$ Only future litigation would provide clarity for this uncertainty. New Zealand creditors are of the view that indebted consumers must earn their discharge through financial literacy. ${ }^{112}$

106 Coetzee \& Roestoff (n 68 above) 33.

107 Coetzee \& Roestoff (n 68 above) 2.

108 Coetzee \& Roestoff (n 1 above) 6.

1092019 National Credit Amendment Act (n 7 above) sec 1(b).

110 Brown (n 77 above) 10.

111 Coetzee \& Roestoff (n 1 above) 10. 
Lastly the debt intervention only applies to a credit agreement with a total unsecured debt not exceeding the threshold of R50 $000 .{ }^{113}$ On this threshold it can be said without a doubt that creditors will put more stringent measures in place for accessing credit. This may result in the exclusion of many low-income household credit deserving consumers from the credit market. These low-income consumers would have to make alternative plans to obtain credit, therefore resorting to getting credit from the rogue and unregistered credit providers who charge exorbitant interest.

In conclusion, the debt intervention procedure attempts to remedy unfair discrimination against over-indebted consumers, however this article is of the opinion that, the debt intervention procedure might just do more harm than good. 